\title{
Overview of air pollution and endocrine disorders
}

This article was published in the following Dove Press journal: International Journal of General Medicine

\section{Philippa D Darbre}

School of Biological Sciences, University of Reading, Reading, UK

Correspondence: Philippa D Darbre School of Biological Sciences, Hopkins Building, University of Reading, Whiteknights, Reading, RG6 6UB, UK Tel +44 II8 3787035

Email p.d.darbre@reading.ac.uk

\begin{abstract}
Over recent years, many environmental pollutant chemicals have been shown to possess the ability to interfere in the functioning of the endocrine system and have been termed endocrine disrupting chemicals (EDCs). These compounds exist in air as volatile or semi-volatile compounds in the gas phase or attached to particulate matter. They include components of plastics (phthalates, bisphenol A), components of consumer goods (parabens, triclosan, alkylphenols, fragrance compounds, organobromine flame retardants, fluorosurfactants), industrial chemicals (polychlorinated biphenyls), products of combustion (polychlorinated dibenzodioxins/furans, polyaromatic hydrocarbons), pesticides, herbicides, and some metals. This review summarizes current knowledge concerning the sources of EDCs in air, measurements of levels of EDCs in air, and the potential for adverse effects of EDCs in air on human endocrine health.
\end{abstract}

Keywords: air pollution, endocrine disruptors, particulate matter

\section{Introduction}

All terrestrial animals with lungs are dependent on the supply of oxygen from air, and pollution of air can result in the inadvertent intake of many undesired components with adverse consequences. According to the World Health Organization (WHO), air pollution caused the death of 6.5 million people worldwide in $2012 .{ }^{1}$ Of this global mortality, about 3 million deaths were caused by outdoor air pollution, but this varied markedly according to geographic location, with the highest values recorded in the Democratic People's Republic of Korea (238.4 deaths per 100,000 population) and the lowest values recorded in Brunei Darussalam and in Australia/Sweden (0.2 and 0.4 per 100,000 population, respectively). ${ }^{1}$ However, WHO has attributed an even greater number of deaths to indoor air pollution, and, in 2012, they estimated this to be about 4 million people globally, largely resulting from heating and cooking with solid fuels in an indoor environment without adequate ventilation. ${ }^{2}$

Pollutants may be natural or man-made, and they may occur as gases, liquid droplets, or solid particles as summarized in Table 1. Gaseous components of air pollution include carbon dioxide and carbon monoxide, sulfur oxides, nitrogen oxides, ammonia, and ground-level ozone. ${ }^{1-3}$ Particulate matter (PM) includes dust, soil, acids, organic molecules, and some metals. ${ }^{4}$ It is categorized according to the size of the particles, with particles of diameter $2.5-10 \mu \mathrm{m}$ considered coarse $\left(\mathrm{PM}_{10}\right),<2.5 \mu \mathrm{m}$ fine $\left(\mathrm{PM}_{2.5}\right)$, and $<0.1 \mu \mathrm{m}$ ultrafine $\left(\mathrm{PM}_{0.1}\right){ }^{4}$ Distributed between the gaseous and particulate phases are also a range of organic pollutant molecules which may exist as volatile organic compounds (VOCs) or semi-volatile organic compounds (SVOCs) in gaseous form 
Table I Origins of air pollution from natural sources and from human activities

\begin{tabular}{|c|c|c|c|}
\hline Form & Compound(s) & Source - natural & Source - human activity \\
\hline \multirow[t]{7}{*}{ Gases } & Carbon dioxide $\left(\mathrm{CO}_{2}\right)$ & $\begin{array}{l}\text { Natural component - } \\
\text { balanced between use } \\
\text { in plant photosynthesis } \\
\text { and release from animal } \\
\text { respiration }\end{array}$ & $\begin{array}{l}\text { Human activity is increasing levels especially through } \\
\text { burning of fossil fuels and deforestation }\end{array}$ \\
\hline & Carbon monoxide & Wild fires & $\begin{array}{l}\text { Incomplete combustion of fuel (natural gas, coal, wood, } \\
\text { petrol) }\end{array}$ \\
\hline & $\begin{array}{l}\text { Sulfur oxides, especially sulfur } \\
\text { dioxide }\left(\mathrm{SO}_{2}\right)\end{array}$ & Volcanoes & $\begin{array}{l}\text { Industrial activities; excess combines with atmospheric } \\
\text { water to cause acid rain }\end{array}$ \\
\hline & $\begin{array}{l}\text { Nitrogen oxides, especially } \\
\text { nitrogen dioxide }\end{array}$ & Thunderstorms & High-temperature combustion \\
\hline & Ammonia & & Agricultural processes \\
\hline & Ground-level ozone & & Combustion of fossil fuel \\
\hline & Volatile organic compounds & $\begin{array}{l}\text { Natural methane; vegetation; } \\
\text { animal and vegetable waste; } \\
\text { sewage }\end{array}$ & $\begin{array}{l}\text { Excess methane from industrial and agricultural } \\
\text { processes; industrial pollutants; waste incineration } \\
\text { (including burning of plastics); chlorofluorocarbons (air } \\
\text { conditioners, refrigerators, aerosol sprays); consumer } \\
\text { products (especially with added fragrance or volatile } \\
\text { solvents) }\end{array}$ \\
\hline $\begin{array}{l}\text { Particulate matter } \\
\text { (solid particles and } \\
\text { liquid droplets) }\end{array}$ & $\begin{array}{l}\text { Dust, soil, acids, organic } \\
\text { molecules including persistent } \\
\text { organic pollutants, metals }\end{array}$ & $\begin{array}{l}\text { Volcanoes, dust storms, } \\
\text { forest fires, sea spray }\end{array}$ & $\begin{array}{l}\text { Fuel combustion (motor vehicles, marine vessels, } \\
\text { aircraft); power plants; industrial processes; cigarette } \\
\text { smoking; consumer products (especially with volatile } \\
\text { solvents or added fragrance); aerosol sprays (pesticides, } \\
\text { herbicides, household cleaners, paints, glues, personal } \\
\text { care products) }\end{array}$ \\
\hline $\begin{array}{l}\text { Radioactive } \\
\text { pollutants }\end{array}$ & & $\begin{array}{l}\text { Radon gas from radioactive } \\
\text { decay }\end{array}$ & Nuclear explosions \\
\hline
\end{tabular}

Note: Shaded areas indicate sources of EDCs.

Abbreviation: EDCs, endocrine disrupting chemicals.

or which may attach to PM. Some of these compounds are now known to have profound effects on the functioning of the endocrine system and have been termed endocrine disrupting chemicals (EDCs). ${ }^{5}$ Whilst much has been written over the past two decades of the actions of EDCs from oral and dermal exposure, research is increasingly documenting their presence in air which opens a debate on the potential for adverse consequences from inhalation of EDCs. This review aims to summarize current knowledge concerning the sources of EDCs in air, measurements of levels of the EDCs in outdoor versus indoor air, and the potential for adverse effects on human endocrine health.

\section{What are EDCs?}

An EDC is defined as "an exogenous substance that causes adverse health effects in an intact organism, and/or its progeny, consequent to changes in endocrine function." ${ }^{\circ} \mathrm{Normal}$ function of the endocrine system is dependent on hormones which act as chemical messengers to regulate physiological functions. Hormones are secreted by glands distributed around the body and are carried by the blood (as conjugates and/or bound to carrier proteins) to act on target cells of distant organs. At the target cells, the hormones act through binding to specific cellular receptors which then relay signals into the cell. Intracellular signaling may involve genomic and/ or non-genomic mechanisms. ${ }^{5} \mathrm{By}$ the genomic mechanism, a hormone binds to a receptor, displacing receptor-associated chaperone proteins and enabling dimerization of the receptors. The receptor dimers then act by binding to specific "response element" nucleotide sequences in the DNA to cause alteration to gene expression. By the non-genomic mechanisms, a hormone may bind to cell surface receptors triggering intracellular signal transduction pathways.

EDCs can interfere in the action of hormones at many different steps, as illustrated in Figure 1. They may act by altering hormone synthesis in the endocrine gland, or through altering transport of the hormone to the target organ by interfering with the activity of conjugation enzymes or by competing for binding to carrier proteins. Alternatively, they may act through altering metabolism/excretion of the hormone or through competing with the hormone for binding to a receptor in target cells and in so doing to mimic 


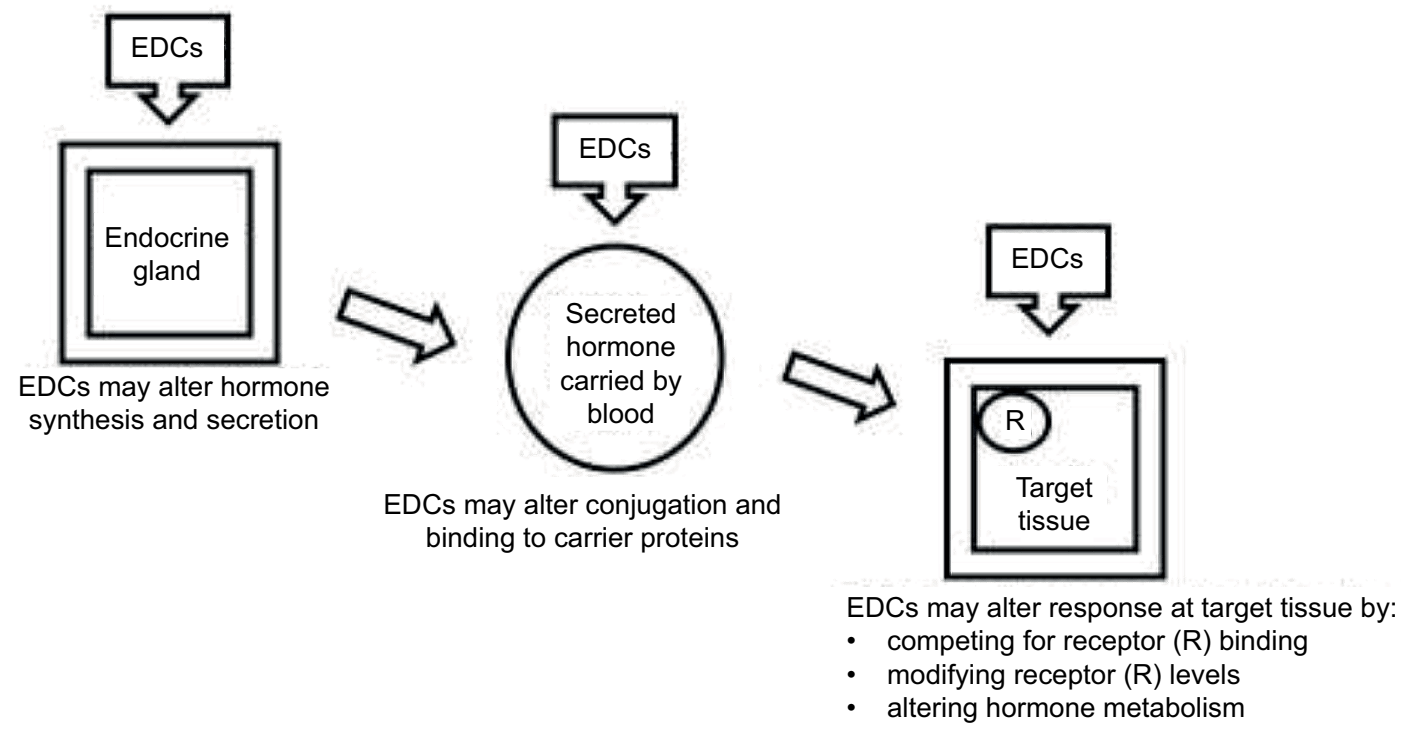

Figure I Mechanisms of action of EDCs.

Note: Data from Darbre. ${ }^{5}$

Abbreviation: EDCs, endocrine disrupting chemicals.

inappropriately or antagonize hormone actions. ${ }^{5}$ Most of the reported disruptive activity has been in relation to the action of steroid hormones (particularly, but not exclusively, in relation to the action of estrogens and androgens) and thyroid hormones. ${ }^{5}$ Since estrogens and androgens regulate reproductive functions, many of the reported effects of the exposure to EDCs have been on adverse consequences for reproductive health. ${ }^{5}$ However, physiological consequences have been demonstrated as resulting from disruption to thyroid function and alterations to thyroid hormone levels. ${ }^{5}$ More widely, adverse effects have also been reported as resulting from alterations to adrenocortical function, impairment of the immune system, and the loss of control on energy metabolism including development of obesity, diabetes, and cardiovascular disease. ${ }^{5}$ Prior to and just after birth are especially vulnerable times for exposure to EDCs because disruption of hormonal activity in the developing embryo/ fetus or young baby can have consequences for health in adult life most notably on reproductive abilities, brain function, immunity, and metabolic programming. ${ }^{5}$ For this reason, the passage of EDCs across the placenta from mother to child and postnatal exposure to EDCs in maternal breast milk have become an important topic for research.

Man-made EDCs are contained within many agricultural, industrial, and consumer products, which due to their widespread use, have become ubiquitous environmental pollutants. This includes components of pesticides and herbicides used both in an agricultural setting and in urban environments. It includes industrial chemicals and by-products of combustion from vehicles, ships, and aircraft. It also includes plastics which are used widely in building materials, food containers, water bottles and toys, and detergents used for cleaning in both industrial and domestic applications. Paints, glues, chemicals used as flame retardants, and stain resistance coatings also form part of the list. EDCs are also widely used in personal care products (PCPs) for purposes of preservation, deodorant, antiperspirant, conditioning, and fragrance. ${ }^{5}$

Many varied assay strategies have been developed over the years for identifying compounds with endocrine disrupting properties in order to define a series of events at different levels of biological organization along a pathway which may lead to an adverse health outcome. ${ }^{5}$ Identification of adverse consequences along a pathway may include altered molecular events, changes to cellular actions, consequences for whole organ responses, or even adverse effects at a population level. Molecular assays include the ability of compounds to bind to specific endocrine receptors followed by assays for genomic actions on gene expression or for non-genomic actions on alterations to defined signal transduction pathways. Actions at a cellular level are most often defined using proliferation of endocrine-sensitive cells as an easily assayable endpoint. Other more specific assays have been developed to measure alterations to synthesis/transport/metabolism/excretion of steroid and thyroid hormones which may be carried out by measuring the activities of key enzymes or levels of secreted hormones using cellular or animal models. Animal models are also widely used to try to predict whole body responses albeit with the caveat of consideration to species differences. 
It is not always possible to identify actions of every chemical at every step and the challenge for risk assessment is to determine the extent to which early molecular and/or cellular actions may be predictive of later endocrine disease outcomes, and to which effects in animal models can predict for epidemiologically detectable consequences in humans. Specific EDCs which are measurable in air are discussed in the "Sources of exposure to EDCs in air" section together with an outline of the current evidence for their classification as having endocrine disrupting properties.

\section{Sources of exposure to EDCs in air}

EDCs are found in both outdoor ${ }^{7}$ and indoor ${ }^{8}$ air as VOCs or SVOCs in the gas phase or attached to PM (Table 1). Some of the specific-named EDCs are listed in Table 2 with the sources indicated. For outdoor air, the type and quantity of pollutants vary according to geographical location, according to whether the site is urban or rural, ${ }^{1}$ and with variations between day and night. ${ }^{9}$ Although indoor air is supplied by outdoor air, it can be additionally polluted by internal activities such as heating or cooking using solid fuel, and is further influenced in the modern world through reduced ventilation, dependence on air conditioning systems, and usage of chemical-based consumer products. ${ }^{8}$ It is this new indoor air microenvironment which seems to provide the greatest exposure to EDCs and this will vary according to individual lifestyle choices.

Outdoor air may contain a range of EDCs from agricultural spraying, industrial activities, and waste incineration. It may also contain EDCs from combustion including petrol and diesel fumes. ${ }^{7}$ However, indoor air may be additionally polluted from the use of consumer products ${ }^{8}$ in a confined space without adequate ventilation and especially from those in aerosol formats. EDCs are contained in domestic pesticide sprays, air fresheners, laundry detergents, household cleaners, paints, adhesives, and plastics, all of which may be used routinely indoors. They are sprayed as flame retardants and stain resistance coatings onto soft furnishings including beds, chairs, sofas, carpets, and curtains used in domestic, workplace, and commercial indoor environments, and furthermore, they are used in a range of PCPs, many of which are in aerosol formats. EDCs are also found in cigarette smoke and may be measured therefore in the indoor air environment where cigarettes have been smoked. As a result, many EDCs are now measurable in indoor air and in indoor dust, often at higher levels than in outdoor air ${ }^{10,11}$ as discussed below.

Table 2 Sources of endocrine disrupting chemicals measured in air

\begin{tabular}{|c|c|c|}
\hline Chemical & Use & Source of air pollution \\
\hline Phthalates & $\begin{array}{l}\text { Plasticizers to increase flexibility and } \\
\text { transparency of plastic products }\end{array}$ & Plastics, personal care products, air fresheners \\
\hline Bisphenol A & $\begin{array}{l}\text { Manufacture of polycarbonate plastic and epoxy } \\
\text { resins }\end{array}$ & $\begin{array}{l}\text { Plastic consumer goods, bottles, sports equipment, } \\
\text { CDs, DVDs, coating pipes and food cans, thermal } \\
\text { paper }\end{array}$ \\
\hline Parabens & Preservatives to prevent microbial action & $\begin{array}{l}\text { Personal care products, pharmaceuticals, paper } \\
\text { products }\end{array}$ \\
\hline Triclosan & Antimicrobial & $\begin{array}{l}\text { Hospital scrub, personal care products, kitchen } \\
\text { utensils, toys }\end{array}$ \\
\hline Alkylphenols & Detergents & Cleaning products, personal care products \\
\hline Synthetic musks & Fragrance & $\begin{array}{l}\text { Personal care products, household cleaning agents, air } \\
\text { fresheners, candles }\end{array}$ \\
\hline Polybrominated diphenyl ethers & Flame retardants & Soft furnishings \\
\hline $\begin{array}{l}\text { Perfluorooctanoic acid, } \\
\text { perfluorooctanesulfonic acid }\end{array}$ & Stain resistance coatings & Soft furnishings, fabrics \\
\hline Polychlorinated biphenyls & $\begin{array}{l}\text { Industrial lubricants and coolants especially in } \\
\text { electrical products }\end{array}$ & $\begin{array}{l}\text { Restricted use since 1970s but ubiquitous persistent } \\
\text { organic pollutants }\end{array}$ \\
\hline $\begin{array}{l}\text { Polychlorinated dibenzodioxins and } \\
\text { dibenzofurans }\end{array}$ & None & By-products of combustion \\
\hline Polyaromatic hydrocarbons & None & Incomplete combustion of organic materials \\
\hline Organochlorine pesticides & Pesticides & Agricultural and domestic spraying \\
\hline Pyrethroids & Pesticide & Agricultural and domestic spraying \\
\hline Cadmium & Cigarettes & Cigarette smoke \\
\hline Aluminum salts & Antiperspirant & Aerosol-format personal care products \\
\hline
\end{tabular}




\section{Phthalates}

Phthalates ${ }^{12,13}$ are esters of phthalic acid which are used as plasticizers not only in plastic products but also in many other consumer goods such as adhesives, paints, air fresheners, and PCPs, making many of the esters high production volume chemicals. ${ }^{14}$ The phthalates are physically bound into the plastics but not by covalent bonding and so leaching out can occur especially with heat and age. Phthalates are ubiquitous in the indoor environment, and in a study in the Richmond area of the USA were measured as present in $100 \%$ of homes..$^{10}$ The more volatile phthalates, dimethyl phthalate, diethyl phthalate (DEP), and dibutyl phthalate (DBP), are present at higher concentrations in air than the heavier, less volatile phthalates such as di(2-ethylhexyl)phthalate (DEHP) and butylbenzylphthalate (BBP) which are more prevalent in house dust. ${ }^{15,16}$ Higher ambient temperatures are associated with higher air concentrations of phthalates ${ }^{17}$ and the presence of polyvinyl chloride flooring has been associated with higher levels of DEHP and BBP in house dust. ${ }^{18,19}$ Phthalate metabolites have been detected in almost all human urine samples indicating widespread exposure of the population. ${ }^{20}$ Diet is generally considered as the main route of exposure, but dermal absorption from topical application of PCPs has been demonstrated ${ }^{21}$ and indoor air may also contribute to the overall burdens. In particular, correlations have been observed between levels of urinary metabolites of DEP, DBP, and BBP with personal indoor air concentrations of the parent phthalates. ${ }^{22,23}$

Phthalates are well established as EDCs with estrogen/ androgen disrupting properties demonstrated. ${ }^{24,25}$ Early studies in vitro showed that phthalate esters could bind to estrogen receptors, stimulate estrogen-dependent gene expression, and increase growth of estrogen-responsive cells..$^{24,25}$ Subsequently, many in vivo models have demonstrated that in utero exposure to phthalates impacts negatively on reproductive development in rodents with a striking similarity to the testicular dysgenesis syndrome in humans ${ }^{26}$ suggesting that phthalate exposure may adversely impact on male reproductive health.

\section{Bisphenol A}

Bisphenol $\mathrm{A}$ is used for its cross-linking properties in the manufacture of polycarbonate plastics and epoxy resins, which are now ubiquitous in our daily lives, and is therefore a high production volume chemical. ${ }^{14}$ It is estimated that $>8$ billion pounds (3.6 million metric tons) of bisphenol A are produced annually and $\sim 100$ tons are released into the atmosphere each year. ${ }^{27}$ Bisphenol $\mathrm{A}$ is now an ubiquitous pollutant of air with levels ranging over several orders of magnitude across different parts of the world, with the highest levels in urban India $\left(200-17,400 \mathrm{pg} / \mathrm{m}^{3}\right)$, but even detectable in polar regions $\left(1-17 \mathrm{pg} / \mathrm{m}^{3}\right) .{ }^{28}$ Correlations have been noted in air between levels of bisphenol A and 1,3,5-triphenylbenzene which is a tracer for plastic burning, suggesting that a source of the atmospheric bisphenol A could be burning of plastic materials. ${ }^{28}$

Bisphenol $\mathrm{A}$ is an established endocrine disrupter. ${ }^{29,30}$ In vitro, it has been shown to bind to estrogen receptors, to stimulate estrogen-dependent gene expression, and to increase proliferation of estrogen-responsive cells, but it can also bind to androgen receptor and demonstrate antiandrogenic actions. Animal models have demonstrated adverse effects on male reproductive function. However, bisphenol A can also bind to thyroid hormone receptors and in vivo animal models record alterations to thyroid hormone levels. Epidemiological studies suggest a link between bisphenol A exposure in humans and multiple adverse endocrine consequences including not only male and female reproductive functions but also alterations to thyroid hormones, blunted immune function, type 2 diabetes, cardiovascular disease, and obesity. ${ }^{29,30}$

\section{Parabens}

The population is exposed to the alkyl esters of p-hydroxybenzoic acid (parabens) through their widespread use as antimicrobial agents for preservation of foods, pharmaceuticals, PCPs, and paper goods. ${ }^{31}$ The main paraben esters used are methylparaben, ethylparaben, propylparaben, butylparaben, and benzylparaben. Intact paraben esters are measurable in human tissues including urine, blood, milk, and breast tissue and are widely detected in the environment in water and soil as well as in animal tissues reflecting widespread contamination. ${ }^{31}$ Unsurprisingly, therefore, parabens are now also being detected in indoor air and house dust. In 2003, a study of homes in Cape Cod detected three paraben esters in indoor air and house dust, with $67 \%$ of homes having levels of methylparaben in the indoor air above the reporting limit of $1 \mathrm{ng} /$ $\mathrm{m}^{3}$ and some as high as $21 \mathrm{ng} / \mathrm{m}^{3} .{ }^{15} \mathrm{In}$ paired indoor:outdoor air samples from the USA, parabens were only detected in indoor air. ${ }^{10}$ Parabens have also been detected in house dust in Spain with methylparaben detected at the highest levels up to $2440 \mathrm{ng} / \mathrm{g}$ and propylparaben up to $910 \mathrm{ng} / \mathrm{g}^{32}$ which is consistent with these esters also being at the highest levels in human tissues and probably reflecting greater use of these esters in consumer products. ${ }^{31,33}$

Parabens have been shown to possess estrogenic and androgenic activity in studies in vitro and in vivo ${ }^{33}$ and their 
presence in human breast tissue has sparked a debate concerning a role in breast cancer development. ${ }^{31}$ However, it has been their reported adverse effects on male reproductive function following perinatal oral exposure in rodents which stimulated regulatory actions. ${ }^{31,33}$ More recently, parabens have been shown to possess obesogenic activity. ${ }^{34}$

\section{Triclosan}

Triclosan [5-chloro-2-(2,4-dichlorophenoxy)phenol] is a chlorinated aromatic compound which has been used as an antimicrobial agent since the 1970s. It was first used as a hospital scrub but has since been incorporated into a wide range of consumer goods including PCPs, kitchen utensils, toys, bedding, and clothing. ${ }^{35}$ Its extensive use has resulted in triclosan being widely measurable in the environment and in human tissues ${ }^{36}$ including urine of the general US population. ${ }^{37}$ It is therefore not surprising that triclosan is now also being detected in indoor air, with concentrations varying according to location; office space was the most contaminated at $230 \mathrm{pg} / \mathrm{m}^{3}$, then apartment space at $153 \mathrm{pg} / \mathrm{m}^{3}$, followed by house space at $104 \mathrm{pg} / \mathrm{m}^{3}$, and day nursery space at $68 \mathrm{pg} / \mathrm{m}^{3} .{ }^{38}$

Triclosan possesses estrogenic and androgenic activities in vitro. ${ }^{39}$ Animal models have demonstrated that it can increase uterine weight in immature rodents (uterotrophic assay) and alter steroidogenesis in vivo. Adverse effects have also been reported on reproductive function in vivo in rodents and aquatic species. ${ }^{40}$

\section{Alkylphenols}

Long-chain alkylphenols and their precursors, alkylphenol ethoxylates, are high production volume chemicals used as surfactants in industrial applications and in common consumer goods such as detergents, disinfectants, and surface cleaners. ${ }^{41,42}$ Alkylphenols such as nonylphenol and octylphenol are now ubiquitously present in the environment ${ }^{41,42}$ and in human urine in the Far East. ${ }^{43,44}$ Studies in outdoor air have demonstrated increased levels above wastewater sites ${ }^{45}$ but, generally, alkylphenols are indoor air contaminants ${ }^{15}$ which are present at higher concentrations in the gas phase than in PM. ${ }^{46}$ Alkylphenols were measured as present in $95 \%$ of homes of the Richmond area of USA. ${ }^{10}$

Alkylphenols, especially nonylphenol and octylphenol, are established EDCs with estrogen disrupting properties reported using assays in vitro ${ }^{47}$ and rodent models in vivo. ${ }^{48}$

\section{Fragrance compounds}

Fragrances have been used since ancient times to mask unpleasant odors. However, traditional plant-based extracts are increasingly being replaced by defined chemical mixtures which are longer lasting. ${ }^{49}$ Chemical-based fragrance is now added ubiquitously to many consumer products including PCPs, household cleaning agents, air fresheners, and scented candles which are used widely both in homes and in public places such as restrooms, hotels, restaurants, cars, trains, and aeroplanes. ${ }^{49}$ One survey reported that scented consumer goods emit $>100$ toxic VOCs including limonene, nitromusks, and polycyclic musks ${ }^{50}$ which together act to degrade indoor air quality. ${ }^{51}$ Synthetic musks galaxolide and tonalide are detectable in indoor air, mainly in the gas phase but also in PM. ${ }^{38}$

Many of these fragrance compounds have now been shown to possess endocrine disrupting properties. ${ }^{49}$ Various musk fragrance compounds have been demonstrated to possess steroid agonist, ${ }^{52}$ or antagonist responses ${ }^{53}$ in reporter gene assays and some can increase proliferation of estrogenresponsive cells. ${ }^{54}$ Some adverse developmental effects of nitromusks have been reported in terms of adverse birth outcomes across species. ${ }^{55}$ One clinical study has reported an association between raised musk xylene and musk ketone levels in women and premenopausal gynecological problems, and notably higher serum levels of musk xylene in women who presented as infertile compared with women who had had at least one pregnancy. ${ }^{56}$

\section{Polybrominated diphenyl ethers (PBDEs)}

$\mathrm{PBDEs}^{57}$ are organobromine compounds used as flame retardants in consumer goods including soft furnishings, clothing, and car components. Structurally, they are composed of two halogenated aromatic rings with 209 congeners according to the number and position of the bromine atoms. Due to their widespread use, they have become ubiquitous environmental contaminants of air as well as animal and human tissues. In air, they are distributed between the gas phase and PM, with the heavier (more bromine atoms) congeners increasingly in the PM. ${ }^{58}$ Levels of PBDEs tend to be not only higher in air of urban than rural areas but also higher in indoor air than in outdoor air. ${ }^{59}$ Although diet is a source of exposure to PBDEs, indoor air has been suggested to be an important route of exposure for the general population ${ }^{60,61}$ together with specific outdoor air occupational exposures of workers at waste recycling plants. ${ }^{62,63}$

Endocrine disruption is an established component of the toxicity of PBDEs including effects on thyroid hormone function $^{64}$ and neurodevelopment. ${ }^{65}$ In vitro models have shown that some PBDEs or their metabolites can bind to thyroid hormone receptors, and animal models have shown 
that PBDEs can alter thyroid hormone levels in vivo. ${ }^{64}$ Early life exposure of animals to PBDEs has revealed alterations to cognitive function/behavior which are critical components for neurodevelopment, and epidemiological studies suggest a similar potential in humans. ${ }^{65}$

\section{Stain resistance coatings}

Perfluorooctanoic acid (PFOA) has been used in the manufacture of consumer goods since the 1940s most notably as "Teflon" and "Gore-Tex". It is used as a water and oil repellent in fabrics and leather, floor waxes, insulators, and firefighting foam. Perfluorooctanesulfonic acid (PFOS) is a fluorosurfactant used most notably as the key ingredient in the fabric protector "Scotchgard" (3M Company, Maplewood, MN, USA), for which production began in 1949 but is now being phased out. Both PFOS and PFOA are highly stable compounds which persist in the environment and can bioaccumulate. PFOA and PFOS are detectable in outdoor air near manufacturing facilities. ${ }^{66,67}$ However, they have also been detected more ubiquitously in house dust globally. ${ }^{68-70}$

Perfluoroalkyl acids (PFAAs) are developmental toxicants with long-lasting effects in reproductive tissues and on the control of metabolism in rodent models. ${ }^{71,72}$ In terms of endocrine disrupting activity, PFOA can alter sex hormone levels, and some PFAAs (although not PFOA or PFOS) possess estrogenic activity in being able to stimulate proliferation of estrogen-responsive cells in vitro. ${ }^{72}$ The main molecular mode of action identified to date seems to be through the activation of peroxisome proliferator activated receptor alpha. ${ }^{72}$

\section{Polychlorinated biphenyls (PCBs)}

$\mathrm{PCBs}^{73}$ were high production organochlorine compounds used as industrial lubricants and coolants, particularly in electrical products due to their low flammability. There are 209 congeners according to the number and configuration of the chlorines, and most were used under trade names as mixtures of congeners. Although their use has been restricted from the 1970s, they have become global pollutants due to their widespread use and environmental stability, and they remain detectable in the air as well as in animal and human tissues. ${ }^{73}$ Levels in air tend to be higher in urban than rural or remote areas, and with the congener composition varying between cities indicating an influence of local sources. ${ }^{74-77}$ Levels in indoor air can be from $10 \times$ to $100,000 \times$ higher than outdoor air probably due to their presence in building materials and consumer goods. ${ }^{8}$ Diet is considered to be the major source of PCB exposure because PCBs, which are lipophilic, pass up the food chain dissolved in animal fat. However, some studies suggest that dietary levels of PCBs are decreasing faster than indoor air concentrations, making inhalation an increasingly important route of exposure ${ }^{61}$ especially in day care centers ${ }^{78}$ and in homes with certain wood floor finish. ${ }^{8}$

Endocrine disruption is a component of the overall toxicity profile of PCBs but the existence of 209 individual congeners presents challenges both for the large number of assays needed to assess effects of so many different compounds (and their metabolites) and for assessing the effects of environmentally relevant mixtures, especially since congener mixtures in human tissues may not be directly reflective of industrial mixtures originally released. Much effort has been given over to assaying the estrogenic potential of the 209 congeners but detailed studies showing estrogenic activity in vitro and in vivo of one congener ${ }^{79}$ have to be supplemented by in silico studies to provide a broader overall picture. ${ }^{80}$ Since estrogen exposure is an established risk factor for breast cancer, much effort has been devoted over the years to epidemiological studies of PCB body burdens in patients with breast cancer. ${ }^{81}$ Such studies remain conflicting and the role of PCBs in breast cancer unresolved. Other effects of PCBs which are better established are their ability to disrupt thyroid homeostasis leading to alterations to thyroid hormone levels ${ }^{82}$ and their neurotoxic actions. ${ }^{83}$ Prenatal exposure from the transplacental passage of PCBs and postnatal exposure from PCBs in breast milk have been suggested to be linked to impairment of neurodevelopment. ${ }^{83}$ In older adults, increased serum levels of PCBs have been linked to cognitive dysfunction typical of neurodegenerative disease..$^{84,85}$

\section{Polychlorinated dibenzodioxins (PBDDs) and polychlorinated dibenzofurans (PBDFs)}

PBDDs $^{86}$ are by-products of combustion and chemical processes. There are 75 congeners of which the most toxic is 2,3,7,8-tetrachlorodibenzodioxin which accounts for about $10 \%$ of dioxin exposure. A main source of dioxins is from the incineration of urban waste ${ }^{87}$ and the dioxins are transported from the site of combustion through the air, to land in the environment, be washed off by rain water into rivers and lakes and thence pass up the food chain dissolved in animal fat. PBDFs ${ }^{86}$ are also by-products of incineration of organochlorine waste and may be inhaled from coal tar, coal tar derivatives, and creosote. Dioxins are measured in outdoor air across the globe from the USA ${ }^{88}$ to China ${ }^{89}$ Levels are generally higher in urban areas than rural areas and can be detected at elevated levels near solid waste plants..$^{90}$ Dioxins are also measurable in indoor dust but levels are usually 
reflective of outdoor conditions..$^{91}$ However, it has been reported that burning incense can increase dioxin levels in indoor air which may therefore cause raised levels in specific indoor environments such as temples or churches. ${ }^{92}$

Dioxins have a broad spectrum of toxicity which includes endocrine disrupting ability. In laboratory animals, they are known to give rise to weight loss, reproductive toxicity, developmental toxicity, tumorigenesis, and immune system dysfunction. ${ }^{93}$ Endocrine actions are thought to be largely mediated through aryl hydrocarbon receptor (AhR)-mediated mechanisms, ${ }^{93,94}$ but there are also defined estrogen antagonist activities mediated through cross-talk between estrogen receptor and AhR pathways. ${ }^{94}$ Clinical studies have reported detrimental effects on human semen quality. ${ }^{95,96}$

\section{Polycyclic aromatic hydrocarbons (PAHs)}

PAHs are a group of organic compounds with two or more fused aromatic rings and which are produced by incomplete combustion of organic materials either naturally from burning of biomass or from human activities such as vehicle emissions, coal burning plants, smoking cigarettes, and from cooking with solid fuels. ${ }^{97}$ PAHs are released into the atmosphere from where they can be ubiquitously deposited into soil and water as persistent contaminants. In air, lowmolecular weight PAHs tend to occur predominantly in the gas phase whereas larger (5+ rings) PAHs tend to be found in PM. ${ }^{97}$ They are measurable globally in outdoor air, although at generally higher levels in less developed countries and at higher levels in urban environments. ${ }^{97}$ Outdoor air PAHs are generated naturally by forest fires and volcanoes but the main sources in the modern world are from industrial plants, waste incineration, and vehicle emissions. ${ }^{97}$ PAHs can be measured in indoor air as well as outdoor air ${ }^{98}$ with the levels in indoor air influenced by the burning of solid fuels for cooking and by smoking of cigarettes. ${ }^{99}$

PAHs have a known toxicity profile and many are genotoxic/carcinogenic. ${ }^{100}$ Their carcinogenicity is thought to result from the ability of some PAHs to form reactive diol epoxide intermediates catalyzed by cytochrome P450 (CYP) enzymes (which may be induced themselves by PAHs through an AhR-mediated mechanism ${ }^{93,94}$ ) and then the subsequent covalent binding of these intermediates to DNA. Carcinogenicity of other PAHs may originate from their ability to generate reactive oxygen species resulting in oxidative stress and inflammatory responses. ${ }^{101}$ However, PAHs are also now regarded as EDCs. ${ }^{101}$ Some PAHs have been reported to act as agonists and others as antagonists of estrogen action. ${ }^{101}$ Agonist actions are mediated by hydroxylated metabolites (with the metabolic conversion itself also mediated by CYP and this inducible by PAHs through an AhR-mediated mechanism) whilst antagonist actions are mediated as described above for the dioxins through cross-talk between AhR and estrogen receptor pathways. ${ }^{94}$

\section{Pesticides}

Pesticides are used widely not only in agricultural settings but also in domestic context from off-the-shelf formulations and in aerosol formats. Some pesticides are organochlorine compounds such as DDT and chlordane which are being phased out due to their environmental persistence. Other pesticides are organophosphates such as chlorpyrifos, carbamates, or pyrethroids. Semi-volatile pesticides are detectable in both indoor air and indoor dust whilst nonvolatile pesticides are usually found only in dust. ${ }^{15,102}$ Concentrations in air are generally higher in warmer weather which increases pesticide volatility, and are therefore higher in places with warmer climates and higher in summer than winter months. ${ }^{102}$ They can be detected in both outdoor and indoor air but degradation rates tend to be lower indoors which typically gives higher levels in indoor air. ${ }^{15,103}$ Many of the banned organochlorine pesticides such as DDT, chlordane, and methoxychlor are established EDCs with estrogenic activities demonstrated in in vitro assays. ${ }^{104,105}$ However, other pesticides are also endocrine disrupting with some pyrethroids possessing androgen and oestrogen disrupting properties ${ }^{106-109}$ and chlorpyrifos having thyroid hormone disrupting actions. ${ }^{10,111}$

\section{Herbicides}

Glyphosate (N-(phosphonomethyl)glycine) ${ }^{112}$ is a broad spectrum systemic herbicide used to kill broadleaf weeds and grasses. It was first marketed in the 1970s under the trade name "Roundup" (Monsanto Company, MO, USA), and was widely adopted in conjunction with glyphosate-resistant crops enabling farmers to kill weeds more effectively without killing the crops. However, it is now also in wide use in the urban environment including domestic gardens. Glyphosate has endocrine disrupting properties, including an ability to interfere in steroidogenesis ${ }^{113}$ and estrogenic activity in in vitro assays of estrogen-responsive gene expression and proliferation. ${ }^{114}$ More recent studies indicate that in utero exposure can cause thyroid imbalance in male rats. ${ }^{115}$ The extent to which it is a human carcinogen remains under debate. ${ }^{116}$ Atrazine is a herbicide used widely for broadleaf crops, but also on golf courses and residential lawns. It was banned in the European Union in 2004 but remains in use in many other parts of the world. In USA, as of 2014, atrazine remained the second most 
applied herbicide after glyphosate. Its endocrine disrupting properties were first described in terms of feminization of male gonads in amphibians ${ }^{117}$ but many other studies now describe its ability to cause reproductive dysfunction in rodent and fish models. ${ }^{118}$ Both of these herbicides have now been detected in air and rain in the Mississippi area of the USA. ${ }^{119}$ In the 2007 sampling, glyphosate was detected in $>75 \%$ and atrazine in $>80 \%$ of air and rain samples. ${ }^{119}$

\section{Metals}

Although most EDCs are organic compounds, some metal ions have also been shown to be capable of interfering in estrogen action and these inorganic xenoestrogens have been termed metalloestrogens. ${ }^{120}$ Metalloestrogens include aluminum, antimony, arsenite, barium, cadmium, chromium [Cr(II)], cobalt, copper, lead, mercury, nickel, selenite, tin, and vanadate. ${ }^{120}$ Pollution of the ecosystem with heavy metals is widespread and some can be detected in indoor dust ${ }^{121}$ which implies their presence in the indoor air environment. However, there are some situations in relation to indoor air which deserve special consideration. Cadmium is contained in cigarette smoke and has many endocrine toxicities. ${ }^{122,123}$ Aluminum is used as an active antiperspirant agent in underarm cosmetics often in aerosol formats and aluminum-based antiperspirant use has been linked to breast cancer. ${ }^{124}$ In consideration of the potential adverse effects of inhalation of aluminum from antiperspirant sprays, it is noteworthy that inhalation of aluminum powder by miners to protect against silicosis gave rise to some early signs of reduced cognitive function in exposed workers which might be indicative of neuroendocrine disruption. ${ }^{125}$

\section{Contribution of EDCs in air to overall human body burdens}

From the research discussed above in the section entitled "Sources of exposure to EDCs in air", it is clear that air pollution includes many EDCs and that EDCs are entering human tissues. However, the question then remains as to the extent to which EDCs in air can contribute to the overall EDC body burdens. Over the past several decades, many cases of endocrine disruption in aquatic organisms have been linked directly to concentrations of EDCs in the water environment leading to reproductive problems and consequent population declines. ${ }^{126,127}$ Early work showed that tributyltin in antifouling paints used on the underside of ships was causing imposex and extensive loss of bivalves and gastropods in harbor waters ${ }^{128}$ which after the restriction of tributyltin enabled recovery of marine populations. ${ }^{129}$ Another similar documented scenario has been described in Lake Apopka in Florida, USA following a spill of the pesticide difocol which caused reproductive problems in the alligator population. ${ }^{130}$ However, the long-debated question remains as to whether similar effects might occur in terrestrial animals which inhale air through lungs rather than taking in water over gills. One complicating factor for terrestrial animals, and in particular the human population, is that the exposure to EDCs occurs nowadays through multiple routes, not only inhalation but also oral and dermal, ${ }^{5}$ making it difficult to ascertain the proportion of body burdens which arrive through each route of entry. For all the EDCs discussed above, published evidence demonstrates their presence in air and that they are measurable in human tissues. For some EDCs, there is accumulating evidence that they are linked to a range of human health issues including female and male reproductive problems, endocrine cancers, thyroid and adrenal dysfunction, developmental abnormalities, immune dysfunction, and disorders of energy metabolism, ${ }^{5}$ as summarized in Figure 2. However, what remains uncertain is the extent to which inhalation is a source of the entry of EDCs to the human body. Furthermore, not only is there a question as to the relative importance of inhalation of outdoor versus indoor air, of inhalation of EDCs in gaseous versus PM format, and of inhalation of PM of different sizes, but it has also been recently suggested that for some semi-volatile EDCs, dermal uptake from air may be greater than uptake from inhalation. ${ }^{131}$ This is especially important for considerations of entry of EDCs such as the paraben esters, which would be metabolized in the liver by esterase activity when entering systemically by oral or inhaled routes, but which would escape breakdown in the liver when entering locally by the dermal route..$^{31,33}$

\section{Effects of EDCs in air on human endocrine health}

Dense smogs mixed with sulfur dioxide and smoke in 1930 over the Meuse Valley in Belgium ${ }^{132}$ and in 1952 in London, $\mathrm{UK}^{133}$ demonstrated the lethality of air pollution, and air pollution is now recognized as a significant factor for many respiratory and cardiovascular diseases. ${ }^{1-4}$ Air-borne pollutants also cause disruption to the endocrine system but this is less often discussed, probably because the effects are more chronic than acute and therefore more difficult to link to specific exposures. Studies using environmental mixtures of EDCs collected in samples of indoor air demonstrate that air does contain compounds with demonstrable estrogenic and androgenic activities when applied to in vitro assay systems. ${ }^{11}$ However, whether the presence of these EDCs in indoor air is a specific cause of or contributes to any specific adverse 


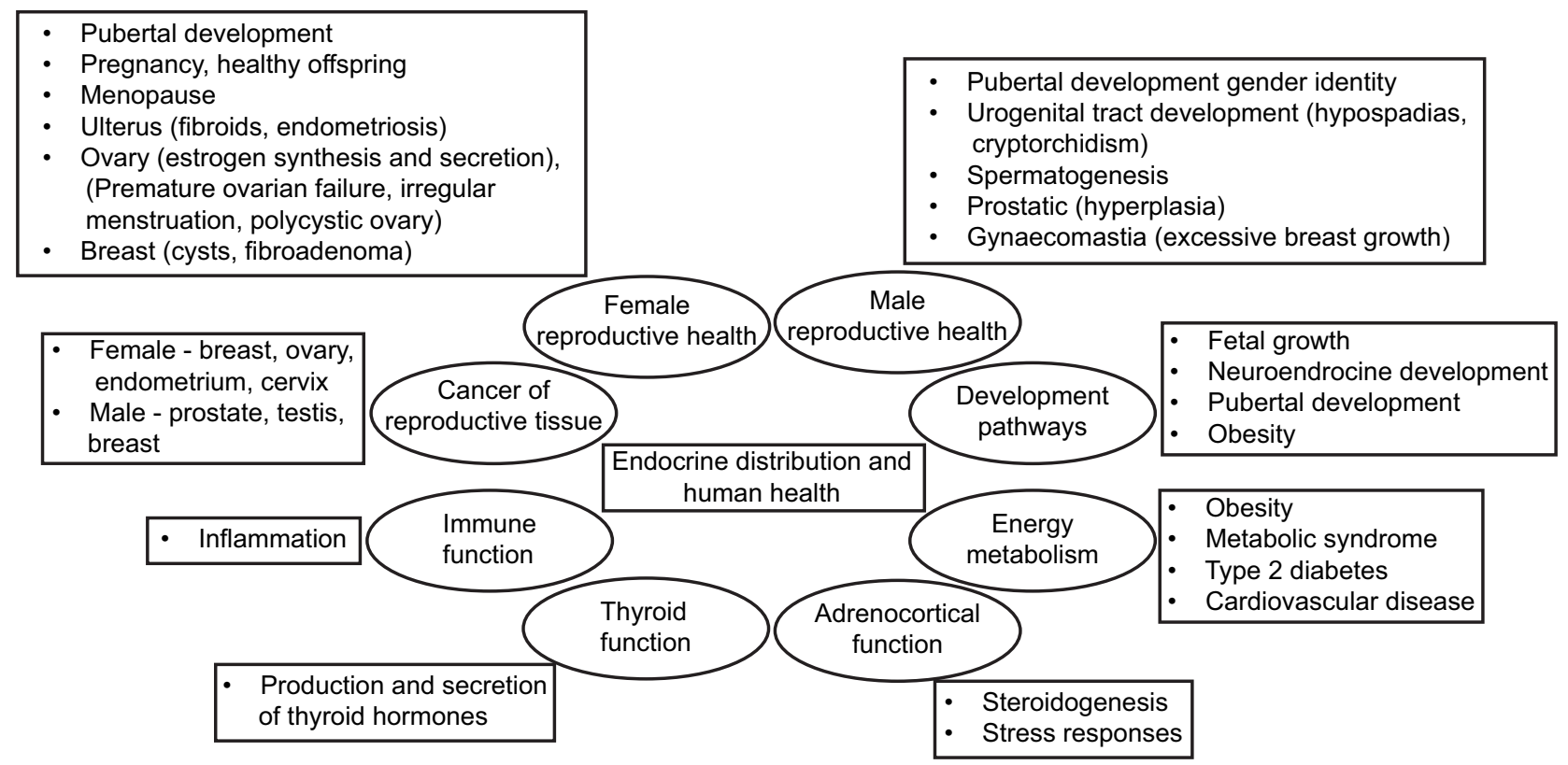

Figure 2 Outline of the influences of EDCs on human health.

Notes: Oval boxes indicate broad health issues affected; square boxes indicate specific effects linked to EDCs. Data from Darbre. ${ }^{5}$

Abbreviation: EDCs, endocrine disrupting chemicals.

human health outcome is difficult to ascertain due to the many different routes of exposure to these same compounds (diet, dermal) in addition to air.

Given the uncertainties of the relative contributions of EDCs from different sources (air, diet, dermal), it is pertinent to begin a discussion of the effects on human endocrine health with specific scenarios where the source of exposure is undoubtedly from air. One specific example where air-borne EDCs can affect the endocrine system is from cigarette smoke, and effects have also even been noted for passive smoking indicating air-borne contaminants as the source. ${ }^{134,135}$ Other special scenarios of air-borne EDCs affecting human endocrine health are discussed in relation to occupational exposure to air-borne material from hops, the use of fragranced air fresheners in indoor spaces, and health issues surrounding traffic-related air pollution.

\section{Cigarette smoking}

Tobacco smoke contains a complex mixture of compounds including EDCs and is known to cause alterations to many hormone levels, thus defining cigarette smoke as endocrine disrupting. ${ }^{134,135}$ Smoking is known to exert effects on the thyroid gland and is an accepted risk factor for thyroid disease including Graves' hyperthyroidism. It causes alterations to thyroid hormone levels, increasing both serum triiodothyronine and thyroglobin concentrations, ${ }^{136}$ and since even paternal smoking increases infant serum thyroglobin, this implies air-borne transfer. Smoking also stimulates the release of several pituitary hormones, causing increases in plasma levels of prolactin, adrenocorticotrophic hormone, growth hormone, and arginine vasopressin proportional to the nicotine intake. ${ }^{137-140}$

The levels of many steroid hormones are also affected by smoking. In terms of adrenal steroids, smoking causes a rise in circulating cortisol, ${ }^{141}$ which is decreased on cessation of smoking, ${ }^{142}$ and also in plasma aldosterone and adrenal androgens. ${ }^{134,135}$ Smoking is known to impact on female reproductive health ${ }^{143}$ at least partly due to effects on the estrogen metabolism together with increased levels of steroid hormone binding globulin which results in lowering concentrations of circulating free estrogens. ${ }^{134,135}$ This results in alterations to the menstrual cycle and risk of anovulation. ${ }^{143-145}$ The reduced estrogen levels are also considered to be the explanation of increased osteoporosis in women who smoke. ${ }^{134,135}$

Smoking has also been linked to insulin resistance in a dose-dependent manner and predisposes to metabolic syndrome. ${ }^{134,135,146}$ More recently, smoking has further been linked to obesity. Whilst moderate smokers have reduced body weight, the dose dependency of weight gain with smoking is actually a U-shaped relationship such that heavy smokers can gain weight, which is in accordance with the non-monotonic nature of endocrine disrupting mechanisms. ${ }^{147}$ Of current 
concern are studies which now link prenatal exposure to smoking as a cause of childhood obesity ${ }^{148,149}$ and even from paternal smoking which implies air-borne components. ${ }^{150}$ Imprinting mechanisms imply that there may also be consequences for future generations without the need for further exposure $^{151}$ as has been demonstrated for EDCs. ${ }^{5}$

\section{Occupational exposure to hops}

Phytoestrogens are compounds contained within plant material and which possess estrogenic properties. ${ }^{152}$ One special scenario where air-borne phytoestrogens have been reported to adversely influence human endocrine health has been in the context of the hop industry, where inhalation of dust from the preparation of hop material has been known to cause menstrual disturbances in female workers for many years. ${ }^{153}$ The component compound has now been identified as 8-prenylnaringenin, ${ }^{153}$ and this occupational exposure scenario demonstrates the ability of air-borne EDCs to cause adverse endocrine effects in women.

\section{Air fresheners and scented products}

Air fresheners and scented products are now ubiquitously used in indoor environments to mask unpleasant odors and to create a pleasant smell by emitting a range of volatile synthetic fragrance compounds, many of which are EDCs as detailed earlier. Adverse human health effects are now being increasingly documented following exposure to these products and include migraine headaches, asthma attacks, contact dermatitis, and mucosal symptoms, ${ }^{49,154}$ but the extent to which these health problems stem from hormonal disturbances remains to be ascertained. However, EDCs, such as phthalates and musks, are contained in these products and are now being suspected as contributing to hormonal imbalances underlying the excessive breast growth of men in gynecomastia. ${ }^{49}$ One recent study has identified gynecomastia in young boys following dermal exposure to lavender and tea-tree oils ${ }^{155}$ and therefore inhalation of such oils could potentially also pose a problem for endocrine health.

\section{Insulin resistance and air pollution}

Glucose homeostasis is dependent on hormonal control, most notably through the actions of insulin and glucagon and also adrenalin, cortisol, and estrogens, and there is increasing evidence that EDCs may be contributing to causing glucose imbalances in insulin resistance and type 2 diabetes. ${ }^{5}$ Type 2 diabetes is one of the fastest growing worldwide health problems $^{5}$ and therefore causative factors which could be avoided would offer a preventative strategy. Several studies now report a link between PM from traffic-related air pollution and insulin resistance ${ }^{156-158}$ and the most recent paper reports PM to be a risk factor for type 2 diabetes especially in a subsection of the population with a prediabetic condition. ${ }^{158}$ It will now be important to identify the components in the PM of air traffic pollution which may be causative and whether these may be EDCs.

\section{Reproductive abnormalities and air pollution}

EDCs are known to impact on both female and male reproductive health. ${ }^{5}$ Concerns for adverse effects of exposure to exogenous estrogen stem from the development of rare vaginal cancers in women prescribed diethylstilboestrol during pregnancy and then the subsequent adverse reproductive health outcomes in both their daughters and sons who were only exposed in utero. ${ }^{159}$ More recent research is beginning to reveal evidence that exposures to various EDCs can lead to a range of adverse reproductive outcomes, such as for the link between exposure to bisphenol A and development of polycystic ovary syndrome, ${ }^{160}$ and between exposure to phthalates and testicular dysgenesis syndrome. ${ }^{26}$ In terms of this review specifically, the question is as to how much of the relevant exposures originate from inhalation of air compared to oral and dermal exposures. Traffic-related studies point more specifically to an involvement of air-borne EDCs in infertility. ${ }^{161} \mathrm{~A}$ recent scoping review indicated that exposure to PAHs impacted most notably on female reproductive health in terms of reduced fertility and pregnancy viability which might be explained by the impact of PAHs on the key hormonal regulators luteinizing hormone, follicle stimulating hormone, gonadotrophin releasing hormone, and the enzyme aromatase responsible for synthesis of estrogens. ${ }^{162}$ SVOCs present in the air and PM are suspected also of having effects on male reproductive function in particular through reduced sperm quality and reduced serum testosterone concentrations. ${ }^{163} \mathrm{~A}$ recent study has also indicated that exposure to air pollution through early life was negatively associated with pubertal stage in both boys and girls although the type of pollutant varied $\left(\mathrm{PM}_{10}\right.$ for girls, sulfur dioxide and nitrogen dioxide for boys). ${ }^{164}$ In another study of traffic-related air pollution, it was found that girls reached puberty several months earlier in residential areas closer to major roads ${ }^{165}$ but again the culprit chemicals remain to be identified.

\section{Developmental abnormalities and air pollution}

Transplacental transfer of EDCs from a mother to the embryo/ fetus is increasingly reported as causing hormonal disruption 
to developmental processes with long-term consequences both in adult life and for future generations. ${ }^{5}$ Exposure to $\mathrm{PM}_{2.5}$ air pollution has been linked to adverse gestational outcomes, ${ }^{166}$ but a recent epidemiological study in Belgium has reported that $\mathrm{PM}_{2.5}$ exposure in the third trimester of pregnancy is associated not only with reduced birth weight but also alteration to fetal thyroid hormones. ${ }^{167}$

\section{Endocrine cancers and air pollution}

Cancer is a complex, multistep process, often taking many decades for visible symptoms to become evident, and requiring exposure to multiple agents for development of all the hallmarks, ${ }^{168}$ which in the case of endocrine-responsive cancers, may also involve exposure to EDCs. ${ }^{5}$ Although airborne cigarette smoke is the main cause of lung cancer, other components of air pollution can also increase the incidence of lung cancer ${ }^{169,170}$ and air-borne asbestos particles are a main cause of mesothelioma through disruption to cytokinesis in the target cells. ${ }^{171}$ Air pollution is therefore now considered to be carcinogenic ${ }^{172}$ and contains multiple agents capable of causing genomic instability ${ }^{173}$ which is an underlying characteristic of cancer development. ${ }^{168}$ However, evidence is also accumulating that the incidence of endocrine-sensitive breast cancer may also be increased by traffic-related air pollution ${ }^{174-176}$ and especially in relation to PAH content. ${ }^{177}$ The mechanism remains to be unraveled, specifically whether the air pollutants may be providing just the source of genotoxic compounds or provide also the endocrine stimuli from EDCs. Another endocrine-sensitive cancer is cervical cancer, and although human papilloma virus (HPV) infection is a main cause of cervical cancer, not all women infected with HPV develop cervical cancer indicating the involvement of other risk factors. In this context, it may be significant that traffic-related air pollutants, including PAHs, have been shown to increase cervical dysplasia, a precursor lesion for cervical cancer. ${ }^{178}$

\section{Conclusion and data gaps}

In conclusion, there is a considerable body of evidence documenting the presence of EDCs in both outdoor and indoor air, that EDCs are entering human tissues, and that EDCs are impacting on human endocrine health. However, the extent to which air-borne EDCs contribute to the overall human body burdens of EDCs is unknown, and instances where endocrine abnormalities can be related directly and solely to an airborne source of EDCs are few. It is likely that the overall environmental reality is that human body burdens of EDCs originate from a range of exposures including diet and dermal as well as air, and that most human health effects result from chemical mixtures rather than individual chemicals.

\section{Recommendations and future directions}

Despite the uncertainty of source, we should not deter from the urgent need to reduce exposure to EDCs if global endocrine health is to be preserved, and this will ultimately require reducing exposure from all sources including air as well as oral and dermal. Whilst it is increasingly acknowledged that personal choices can result in reduced oral and dermal exposures to EDCs, the same could also be true for inhalation by personal choices of reducing use of chemicals, especially in indoor spaces and in aerosol format, and increasing ventilation in indoor spaces. A public education program in the handling of chemical-based products would be highly appropriate in the modern world, and it is highly likely that new public awareness could have immense health benefits. It is interesting that individuals with asthma have been reported to have a lower risk of breast cancer, ${ }^{179}$ and it could be speculated that the reduced cancer risk might originate from an awareness of asthma causing pollutants, which then spills over into a new lifestyle of pollution avoidance.

Some of the challenges in understanding the action of EDCs are different from generally accepted toxicological approaches, not least because their action through biological receptor-based signaling pathways enables them to act at much lower concentrations than the nonspecific actions of general toxicity, but also because many of their responses are not predictable and may follow non-monotonic patterns. ${ }^{147}$ Furthermore, since multiple different compounds may act by a similar mechanism through binding to the same receptor, they can substitute for one another ${ }^{180}$ and thus confound epidemiological studies, which tend to be based on the assumption of a single component alone being causative. In multistep processes, such as cancer, they may also be able to act by complementary mechanisms, ${ }^{180}$ which would also confuse epidemiological work. Indeed, a recent multinational project has concluded that unraveling the causes of cancer will need to take into account the effects of long-term lowdose exposures to complex mixtures of chemicals. ${ }^{181}$ In this context, there needs to be a new realization not only by the general public but also by regulatory bodies that the action of EDCs may be far more complex than currently accredited, involving additive and/or complementary actions of a wide range of different chemical compounds from a large number of different sources to which air pollution needs to be increasingly added as a significant component. 


\section{Disclosure}

The author reports no conflicts of interest in this work.

\section{References}

1. World Health Organization. Factsheet 313. Ambient (outdoor) air quality and health. [updated September 2016]. Available from: http:// www.who.int/mediacentre/factsheets/fs313/en/.

2. World Health Organization. Factsheet 292. Household air pollution and health. [updated February 2016]. Available from: http://www.who. int/mediacentre/factsheets/fs292/en/.

3. Najjar YSH. Gaseous pollutants formation and their harmful effects on health and environment. Innovative Energy Policies. 2011;1:E101203:1-8

4. Anderson JO, Thundiyil JG, Stolbach A. Clearing the air: a review of the effects of particulate matter air pollution on human health. $J \mathrm{Med}$ Toxicol. 2012;8:166-175.

5. Darbre PD. Endocrine Disruption and Human Health. Elsevier: New York; 2015.

6. Report of the Proceedings of the European workshop on the impact of endocrine disrupters on human health and wildlife. Weybridge, UK. Report EUR17549 of the Environment and Climate Change Research Programme of DGXII of the European Commission; 1996.

7. Teil MJ, Moreau-Guigon E, Blanchard M, et al. Endocrine disrupting compounds in gaseous and particulate outdoor air phases according to environmental factors. Chemosphere. 2016;146:94-104.

8. Rudel RR, Perovich LJ. Endocrine disrupting chemicals in indoor and outdoor air. Atmos Environ. 2009;43:170-181.

9. Novak J, Glesy JP, Hilscherova K. In vitro effects of pollutants from particulate and volatile fractions of air samples - day and night variability. Environ Sci Pollut Res. 2013;20:6620-6627.

10. Rudel RA, Dodson RE, Perovich LJ, et al. Semivolatile endocrinedisrupting compounds in paired indoor and outdoor air in two northern California communities. Environ Sci Technol. 2010;44:6583-6590.

11. Oziol L, Alliot F, Botton J, et al. First characterization of the endocrinedisrupting potential of indoor gaseous and particulate contamination: comparison with urban outdoor air (France). Environ Sci Pollut Res Int. 2017;24:3142-3152.

12. Kamrin MA. Phthalate risks, phthalate regulation and public health: a review. J Toxicol Environ Health Part B. 2009;12:157-174.

13. Huang PC, Liou SH, Ho IK, Chiang H, Huang HI, Wang S. Phthalates exposure and endocrinal effects: an epidemiological review. J Food Drug Analysis. 2012;20:719-733.

14. Organization for Economic Cooperation and Development (OECD). The 2004 OECD List of High Production Volume Chemicals. Paris: Environment Directorate; 2004.

15. Rudel RA, Camann DE, Spengler JD, Korn LR, Brody JG. Phthalates, alkylphenols, pesticides, polybrominated diphenyl ethers, and other endocrine-disrupting compounds in indoor air and dust. Environ $\mathrm{Sci}$ Technol. 2003;37:4543-4553.

16. Heudorf U, Mersch-Sundermann V, Angerer J. Phthalates: toxicology and exposure. Int J Hyg Environ Health. 2007;210:623-634.

17. Uhde E, Bednarek M, Fuhrmann F, Salthammer T. Phthalic esters in the indoor environment - test chamber studies on PVC coated wallcoverings. Indoor Air. 2001;11:150-155.

18. Bornehag CG, Sundell J, Weschler CJ, et al. The association between asthma and allergic symptoms in children and phthalates in house dust: a nested case-control study. Environ Health Perspect. 2004;112:1393-1397.

19. Bornehag CG, Lundgren B, Weschler CJ, Sigsgaard T, HagerhedEngman L, Sundell J. Phthalates in indoor dust and their association with building characteristics. Environ Health Perspect. 2005;113:1399-1404.

20. Silva MJ, Barr DB, Reidy JA, et al. Urinary levels of seven phthalate metabolites in the U.S. population from the National Health and Nutrition Examination Survey (NHANES) 1999-2000. Environ Health Perspect. 2004;112:331-338.
21. Janjua NR, Frederiksen H, Skakkebaek NE, Wulf HC, Andersson AM. Urinary excretion of phthalates and paraben after repeated whole-body topical application in humans. Int J Androl. 2008;31:118-130.

22. Adibi JJ, Perera FP, Jedrychowski W, et al. Prenatal exposures to phthalates among women in New York City and Krakow, Poland. Environ Health Perspect. 2003;111:1719-1722.

23. Adibi JJ, Whyatt RM, Williams PL, et al. Characterization of phthalate exposure among pregnant women assessed by repeat air and urine samples. Environ Health Perspect. 2008;116:467-473.

24. Jobling S, Reynolds T, White R, Parker MG, Sumpter JP. A variety of environmentally persistent chemicals, including some phthalate plasticizers, are weakly estrogenic. Environ Health Perspect. 1995;103: 582-587.

25. Harris CA, Henttu P, Parker MG, Sumpter JP. The estrogenic activity of phthalate esters in vitro. Environ Health Perspect. 1997;105:802-811.

26. Howdeshell KL, Hotchkiss AK, Gray LE. Cumulative effects of antiandrogenic chemical mixtures and their relevance to human health risk assessment. Int J Hyg Environ Health. 2017;220:179-188.

27. Staples CA, Dorn PB, Klecka GM, et al. A review of the environmental fate, effects, and exposures of bisphenol A. Chemosphere. 1998;36:2149-2173.

28. Fu P, Kawamura K. Ubiquity of bisphenol A in the atmosphere. Environ Pollut. 2010;158:3138-3143.

29. Rubin BS. Bisphenol A: an endocrine disruptor with widespread exposure and multiple effects. J Steroid Biochem Mol Biol. 2011;127:27-34.

30. Rochester JR. Bisphenol A and human health: a review of the literature. Reprod Toxicol. 2013;42:132-155.

31. Darbre PD, Harvey PW. Parabens can enable hallmarks and characteristics of cancer in human breast epithelial cells: a review of the literature with reference to new exposure data and regulatory status. J Appl Toxicol. 2014;34:925-938.

32. Ramirez N, Marce RM, Borrull F. Determination of parabens in house dust by pressurised hot water extraction followed by stir bar sorptive extraction and thermal desorption-gas chromatography-mass spectrometry. J Chromatog A. 2011;1218:6226-6231.

33. Darbre PD, Harvey PW. Paraben esters: review of recent studies of endocrine toxicity, absorption, esterase and human exposure, and discussion of potential human health risks. $J$ Appl Toxicol. 2008;28:561-578.

34. Darbre P. Endocrine disruptors and obesity. Curr Obes Rep. 2017;6:18-27.

35. Dann AB, Hontela A. Triclosan: environmental exposure, toxicity and mechanisms of action. J Appl Toxicol. 2011;31:285-311.

36. Huang CL, Abass OK, Yu CP. Triclosan: a review on systematic risk assessment and control from the perspective of substance flow analysis. Sci Total Environ. 2016;566-567:771-785.

37. Li S, Zhao J, Wang G, et al. Urinary triclosan concentrations are inversely associated with body mass index and waist circumference in the US general population: Experience in NHANES 2003-2010. Int J Hyg Environ Health. 2015;218:401-406.

38. Laborie S, Moreau-Guigon E, Alliot F, Desportes A, Oziol L, Chevreuil $\mathrm{M}$. A new analytical protocol for the determination of 62 endocrinedisrupting compounds in indoor air. Talanta. 2016;142:132-141.

39. Gee RH, Charles A, Taylor N, Darbre PD. Oestrogenic and androgenic activity of triclosan in breast cancer cells. J Appl Toxicol. 2008;28 78-91.

40. Wang CF, Tian Y. Reproductive endocrine-disrupting effects of triclosan: population exposure, present evidence and potential mechanisms. Environ Pollut. 2015;206:195-201.

41. Nimrod AC, Benson WH. Environmental estrogenic effects of alkylphenol ethoxylates. Crit Rev Toxicol. 1996;26:335-364.

42. Kovarova J, Blahova J, Divsova L, Svobodova Z. Alkylphenol ethoxylates and alkylphenols - update information on occurrence, fate and toxicity in aquatic environment. Pol J Vet Sci. 2013;16:763-772.

43. Park H, Kim K. Urinary levels of 4-nonylphenol and 4-t-octylphenol in a representative sample of the Korean adult population. Int J Environ Res Public Health. 2017;14:E932. 
44. Peng F, Ji W, Zhu F, et al. A study on phthalate metabolites, bisphenol A and nonylphenol in the urine of Chinese women with unexplained recurrent spontaneous abortion. Environ Res. 2016;150:622-628.

45. Dachs J, Van Ry DA, Eisenreich SJ. Occurrence of estrogenic nonylphenols in the urban and coastal atmosphere of the lower Hudson river estuary. Environ Sci Technol. 1999;33:2676-2679.

46. Weschler CJ. Indoor-outdoor relationships for non-polar organic constituents of aerosol particles. Environ Sci Technol. 1984;18:648-652.

47. White R, Jobling S, Hoare SA, Sumpter JP, Parker MG. Environmentally persistent alkylphenolic compounds are estrogenic. Endocrinology. 1994;135:175-182.

48. Laws SC, Carey SA, Ferrell JM, Bodman GJ, Cooper RL. Estrogenic activity of octylphenol, nonylphenol, bisphenol A and methoxychlor in rats. Toxicol Sci. 2000;54:154-167.

49. Patel S. Fragrance compounds: the wolves in sheep's clothings. Med Hypotheses. 2017;102:106-111.

50. Potera C. Scented products emit a bouquet of VOCs. Environ Health Perspect. 2011;119:A16.

51. Uhde E, Schulz N. Impact of room fragrance products on indoor air quality. Atmos Environ. 2015;106:492-502.

52. Mori $\mathrm{T}$, Iida $\mathrm{M}$, Ishibashi $\mathrm{H}$, et al. Hormonal activity of polycyclic musks evaluated by reporter gene assay. Environ Sci. 2007;14:195-202.

53. Van der Burg B, Schreurs R, Linden S, Seinen W, Brouwer A, Sonneveld E. Endocrine effects of polycyclic musks: do we smell a rat? Int J Androl. 2008;31:188-193.

54. Bitsch N, Dudas C, Korner W, et al. Estrogenic activity of musk fragrances detected by the E-screen assay using human MCF-7 cells. Arch Environ Contam Toxicol. 2002;43:257-264.

55. Taylor KM, Weisskopf M, Shine J. Human exposure to nitro musks and the evaluation of their potential toxicity: an overview. Environ Health. 2014;13:1-7.

56. Eisenhardt S, Runnebaum B, Bauer K, Gerhard I. Nitromusk compounds in women with gynecological and endocrine dysfunction. Environ Res Section A. 2001;87:123-130.

57. World Health Organization. Brominated diphenyl ethers. Environmental Health Criteria 1994; Number 162. Available from: http://www. inchem.org/documents/ehc/ehc/ehc162.htm.

58. Vives I, Canuti E, Castro-Jimenez J, et al. Occurrence of polychlorinated dibenzo-p-dioxins and dibenzofurans (PCDD/Fs), polychlorinated biphenyls (PCBs) and polybrominated diphenyl ethers (PBDEs) in Lake Maggiore (Italy and Switzerland). J Environ Monit. 2007;9:589-598.

59. Hazrati S, Harrad S. Causes of variability in concentrations of polychlorinated biphenyls and polybrominated diphenyl ethers in indoor air. Environ Sci Technol. 2006;40:7584-7589.

60. Allen JG, McClean MD, Stapleton HM, Nelson JW, Webster TF. Personal exposure to polybrominated diphenyl ethers (PBDEs) in residential indoor air. Environ Sci Technol. 2007;41:4574-4579.

61. Harrad S, Hazrati S, Ibarra C. Concentrations of polychlorinated biphenyls in indoor air and polybrominated diphenyl ethers in indoor air and dust in Birmingham, United Kingdom: implications for human exposure. Environ Sci Technol. 2006;40:4633-4638.

62. Deng WJ, Zheng JS, Bi XH, Fu JM, Wong MH. Distribution of PBDEs in air particles from an electronic waste recycling site compared with Guangzhou and Hong Kong, South China. Environ Int. 2007;33:1063-1069.

63. Cahill TM, Groskova D, Charles MJ, Sanborn JR, Denison MS, Baker L. Atmospheric concentrations of polybrominated diphenyl ethers at near source sites. Environ Sci Technol. 2007;41:6370-6377.

64. Zhou T, Taylor MM, DeVito MJ, Crofton KM. Developmental exposure to brominated diphenyl ethers results in thyroid hormone disruption. Toxicol Sci. 2002;66:105-116.

65. Herbstman JB, Mall JK. Developmental exposure to polybrominated diphenyl ethers and neurodevelopment. Curr Environ Health Res. 2014;1:101-112.

66. Barton CA, Butler LE, Zarzecki CJ, et al. Characterizing perfluorooctanoate in ambient air near the fence line of a manufacturing facility: comparing modeled and monitored values. J Air Waste Manag Assoc. 2006;56:48-55.
67. Su H, Lu Y, Wang P, et al. Perfluoroalkyl acids (PFAAs) in indoor and outdoor dusts around a mega fluorochemical industrial park in China: implications for human exposure. Environ Int. 2016;94:667-673.

68. Knobeloch L, Imm P, Anderson H. Perfluoroalkyl chemicals in vacuum cleaner dust from 39 Wisconsin homes. Chemosphere. 2012;88:779-783.

69. Moriwaki H, Takatah Y, Arakawa R. Concentrations of perfluorooctane sulfonate (PFOS) and perfluorooctanoic acid (PFOA) in vacuum cleaner dust collected in Japanese homes. J Environ Monit. 2003;5: 753-757.

70. Eriksson U, Karrman A. World-wide indoor exposure to polyfluoroalkyl phosphate esters (PAPs) and other PFASs in household dust. Environ Sci Technol. 2015;49:14503-14511.

71. Jensen AA, Leffers H. Emerging endocrine disrupters: perfluoroalkylated substances. Int J Androl. 2008;31:161-169.

72. White SS, Fenton SE, Hines EP. Endocrine disrupting properties of perfluorooctanoic acid. J Steroid Biochem Mol Biol. 2011;127:16-26.

73. World Health Organization. Polychlorinated biphenyls and terphenyls. Environmental Health Criteria 1992; Number 140. Available from: http://www.inchem.org/documents/ehc/ehc/ehc140.htm.

74. Harner T, Shoeib M, Diamond M, Stern G, Rosenberg B. Using passive air samplers to assess urban-rural trends for persistent organic pollutants. 1. Polychlorinated biphenyls and organochlorine pesticides. Environ Sci Technol. 2004;38:4474-4483.

75. Motelay-Massei A, Harner T, Shoeib M, Diamond M, Stern G, Rosenberg B. Using passive air samplers to assess urban-rural trends for persistent organic pollutants and polycyclic aromatic hydrocarbons. 2. Seasonal trends for PAHs, PCBs, and organochlorine pesticides. Environ Sci Technol. 2005;39:5763-5773.

76. Shen L, Wania F, Lei YD, Teixeira C, Muir DC, Xiao H. Polychlorinated biphenyls and polybrominated diphenyl ethers in the North American atmosphere. Environ Pollut. 2006;144:434-444.

77. Jamshidi A, Hunter S, Hazrati S, Harrad S. Concentrations and chiral signatures of polychlorinated biphenyls in outdoor and indoor air and soil in a major U.K. conurbation. Environ Sci Technol. 2007;41:2153-2158.

78. Wilson NK, Chuang JC, Lyu C. Levels of persistent organic pollutants in several child day care centers. J Expo Anal Environ Epidemiol. 2001;11:449-458.

79. Nesaretnam K, Corcoran D, Dils RR, Darbre P. 3,4,3',4'-Tetrachlorobiphenyl acts as an estrogen in vitro and in vivo. Mol Endocrinol. 1996;10:923-936.

80. Ruiz P, Ingale K, Wheeler JS, Mumtaz M. 3D QSAR studies of hydroxylated polychlorinated biphenyls as potential xenoestrogens. Chemosphere. 2016;144:2238-2246.

81. Brody JG, Moysich KB, Humblet O, Attfield KR, Beehler GP, Rudel RA. Environmental pollutants and breast cancer: epidemiologic studies. Cancer. 2007;109(12 Suppl):2667-2711.

82. Turyk ME, Anderson HA, Persky VW. Relationships of thyroid hormones with polychlorinated biphenyls, dioxins, furans, and DDE in adults. Environ Health Perspect. 2007;115:1197-1203.

83. Winneke G, Walkowiak J, Lilienthal H. PCB-induced neurodevelopmental toxicity in human infants and its potential mediation by endocrine dysfunction. Toxicology. 2002;181-182:161-165.

84. Bouchard MF, Oulhote Y, Sagiv SK, Saint-Amour D, Weave J. Polychlorinated biphenyl exposures and cognition in older U.S. adults: NHANES (1999-2002). Environ Health Perspect. 2014;122:73-78.

85. Przybyla J, Houseman EA, Smit E, Kile ML. A path analysis of multiple neurotoxic chemicals and cognitive functioning in older US adults (NHANES 1999-2002). Environ. Health. 2017;16:1-11.

86. World Health Organization. Polychlorinated dibenzo-p-dioxins and dibenzofurans. Environmental Health Criteria 1989; Number 88. Available from: http:/www.inchem.org/documents/ehc/ehc/ehc88.htm

87. Shibamoto T, Yasuhara A, Katami T. Dioxin formation from waste incineration. Rev Environ Contam Toxicol. 2007;190:1-41.

88. Dwyer H, Themelis NJ. Inventory of U.S. 2012 dioxin emissions to atmosphere. Waste Manag. 2015;46:242-246.

89. Wang P, Zhang Q, LiY, Matsiko J, Zhang Y, Jiang G. Airborne persistent toxic substances (PTSs) in China: occurrence and its implication associated with air pollution. Environ Sci Process Impacts. 2017;19:983-999. 
90. Caserini S, Cernuschi S, Giugliano M. Air and soil dioxin levels at three sites in Italy in proximity to MSW incineration plants. Chemosphere. 2004;54:1279-1287.

91. Deziel NC, Nuckols JR, Jones RR, et al. Comparison of industrial emissions and carpet dust concentrations of polychlorinated dibenzop-dioxins and polychlorinated dibenzofurans in a multi-center U.S. study. Sci Tot Environ. 2017;580:1276-1286.

92. Hu MT, Chen SJ, Huang KL, et al. Characterisation of, and health risks from, polychlorinateddibenzo-pdioxins/dibenzofurans from incense burned in a temple. Sci Tot Environ. 2009;407:4870-4875.

93. Otarola G, Castillo H, Marcellini S. Aryl hydrocarbon receptor-based bioassays for dioxin detection: thinking outside the box. JAppl Toxicol. Epub 2017 Dec 26.

94. Safe S, Wormke M. Inhibitory aryl hydrocarbon receptor-estrogen receptor $\alpha$ cross-talk and mechanisms of action. Chem Res Toxicol. 2003;16:807-816.

95. Mocarelli P, Gerthoux M, Patterson DG, et al. Dioxin exposure, from infancy through puberty, produces endocrine disruption and affects human semen quality. Environ Health Perspect. 2008;116:70-77.

96. Mocarelli P, Gerthoux PM, Needham LL, et al. Perinatal exposure to low doses of dioxin can permanently impair human semen quality. Environ Health Perspect. 2011;119:713-718.

97. Abdel-Shafy HI, Mansour MSM. Polycyclic aromatic hydrocarbons in indoor and outdoor environments and factors affecting their concentrations. Egypt J Petrol. 2016;25:107-123.

98. Zhu L, Takahashi Y, Amagai T, Matsushita H. Highly sensitive automatic analysis of polycyclic aromatic hydrocarbons in indoor and outdoor air. Talanta. 1997;45:113-118.

99. World Health Organization. WHO Guidelines for Indoor Air Quality. Geneva, Switzerland: WHO; 2010.

100. Straif K, Baan R, Grosse Y, Secretan B, El Ghissassi F, Cogliano $\mathrm{V}$; WHO International Agency for Research on Cancer Monograph Working Group. Carcinogenicity of polycyclic aromatic hydrocarbons. Lancet Oncol. 2005;6:931-932.

101. Zhang Y, Dong S, Wang H, Tao S, Kiyama R. Biological impact of environmental polycyclic aromatic hydrocarbons (ePAHs) as endocrine disruptors. Environ Pollut. 2016;213:809-824.

102. Lewis RG. Pesticides. In: Spengler JD, McCarthy JF, Samet JM, editors. Indoor Air Quality Handbook. New York: McGraw-Hill; 2001:35.1-35.17.

103. Butte W, Heinzow B. Pollutants in house dust as indicators of indoor contamination. Rev Environ Contam Toxicol. 2002;175:1-46.

104. Soto AM, Chung KL, Sonnenschein C. The pesticides endosulfan, toxaphene, and dieldrin have estrogenic effects on human estrogensensitive cells. Environ Health Perspect. 1994;102:380-383.

105. Soto AM, Sonnenschein C, Chung KL, Fernandez MF, Olea N, Serrano FO. The E-SCREEN assay as a tool to identify estrogens: an update on estrogenic environmental pollutants. Environ Health Perspect 1995;103(Suppl 7):113-122.

106. Garey J, Wolff MS. Estrogenic and antiprogestagenic activities of pyrethroid insecticides. Biochem Biophys Res Commun. 1998;251:855-859.

107. Go V, Garey J, Wolff MS, Pogo BG. Estrogenic potential of certain pyrethroid compounds in the MCF-7 human breast carcinoma cell line. Environ Health Perspect. 1999;107:173-177.

108. Kim SS, Kwack SJ, Lee RD, et al. Assessment of estrogenic and androgenic activities of tetramethrin in vitro and in vivo assays. J Toxicol Environ Health Part A. 2005;68:2277-2289.

109. Kim SS, Lee RD, Lim KJ, et al. Potential estrogenic and antiandrogenic effects of permethrin in rats. J Reprod Dev. 2005;51:201-210.

110. Jeong SH, Kim BY, Kang HG, Ku HO, Cho JH. Effect of chlorpyrifosmethyl on steroid and thyroid hormones in rat F0- and F1-generations. Toxicology. 2006;220:189-202.

111. Meeker JD, Barr DB, Hauser R. Thyroid hormones in relation to urinary metabolites of non-persistent insecticides in men of reproductive age. Reprod Toxicol. 2006;22:437-442.
112. World Health Organization. Glyphosate. Environmental Health Criteria 1994; Number 159. Available from: http://www.inchem.org/ documents/ehc/ehc/ehc159.htm.

113. Walsh LP, McCormick C, Martin C, Stocco DM. Roundup inhibits steroidogenesis by disrupting steroidogenic acute regulatory (StAR) protein expression. Environ Health Perspect. 2000;108:769-776.

114. Mesnage R, Phedonos A, Biserni M, et al. Evaluation of estrogen receptor alpha activation by glyphosate-based herbicide constituents. Food Chem Toxicol. 2017;108:30-42.

115. Souza JS, Kizys MML, Conceicao RR, et al. Perinatal exposure to glyphosate-based herbicide alters the thyrotrophic axis and causes thyroid hormone homeostasis imbalance in male rats. Toxicology. 2017;377:25-37.

116. Vandenberg LN, Blumberg B, Antoniou MN, et al. Is it time to reassess current safety standards for glyphosate-based herbicides? J Epidemiol Commun Health. 2017;71:613-618.

117. Hayes TB, Anderson LL, Beasley VR, et al. Demasculinization and feminization of male gonads by atrazine: consistent effects across vertebrate classes. J Steroid Biochem Mol Biol. 2011;127:64-73.

118. Wirbisky SE, Freeman JL. Atrazine exposure and reproductive dysfunction through the hypothalamus-pituitary-gonadal (HPG) axis. Toxics. 2015;3:414-450.

119. Majewski MS, Coupe RH, Foreman WT, et al. Pesticides in Mississippi air and rain: a comparison between 1995 and 2007. Environ Toxicol Chem. 2014;33:1283-1293.

120. Darbre PD. Metalloestrogens: an emerging class of inorganic xenoestrogens with potential to add to the oestrogenic burden of the human breast. J Appl Toxicol. 2006;26:191-197.

121. Tan SY, Praveena SM, Abidin EZ, Cheema MS. A review of heavy metals in indoor dust and its human health-risk implications. Rev Environ Health. 2016;31:447-456.

122. World Health Organization. Cadmium. Environmental Health Criteria 1992; Number 134. Available from: http://www.inchem.org/documents/ehc/ehc/ehc134.htm.

123. Rani A, Kumar A, Lal A, Pant M. Cellular mechanisms of cadmiuminduced toxicity: a review. Int J Environ Health Perspect. 2014;24: 378-399.

124. Darbre PD. Aluminium and the human breast. Morphologie. 2016;100:65-74.

125. Rifat SL, Eastwood MR, McLachlan DRC, Corey PN. Effect of exposure of miners to aluminium powder. Lancet. 1990;336:1162-1165.

126. European Environment Agency (EEA). The impacts of endocrine disrupters on wildlife, people and their environments. The Weybridge+15 (1996-2011) report. Publications Office of the European Union, Luxemburg; 2012.

127. Bergman A, Heindel JJ, Jobling S, Kidd KA, Zoeller RT, editors. The State of the Science of Endocrine Disrupting Chemicals - 2012. United Nations Environment Programme (UNEP) and World Health Organization (WHO); 2013.

128. Horiguchi, T. Masculinization of female gastropod mollusks induced by organotin compounds, focusing on mechanism of actions of tributyltin and triphenyltin for development of imposex. Environ Sci. 2006;13:77-87.

129. Jorundsdottir K, Svavarsson J, Leung KM. Imposex levels in the dogwhelk Nucella lapillus (L.) - continuing improvement at high latitudes. Mar Pollut Bull. 2005;51:744-749.

130. Guillette LJ Jr, Gunderson MP. Alterations in development of reproductive and endocrine systems of wildlife populations exposed to endocrine-disrupting contaminants. Reproduction. 2001;122:857-864

131. Weschler CJ, Nazaroff WW. Dermal uptake of organic vapors commonly found in indoor air. Environ Sci Technol. 2014:48:1230-1237.

132. Nemery B, Hoek P, Nemmar A. The Meuse Valley fog of 1930: an air pollution disaster. Lancet. 2001;357:704-708.

133. Bell ML, Davis DD. Reassessment of the lethal London fog of 1952 : novel indicators of acute and chronic consequences of acute exposure to air pollution. Environ Health Perspect. 2001;109:389-394. 
134. Kapoor D, Jones TH. Smoking and hormones in health and endocrine disorders. Eur J Endocrinol. 2005;152:491-499.

135. Tweed JO, Hsia SH, Lutfy K, Friedman TC. The endocrine effects of nicotine and cigarette smoke. Trends Endocrinol Metab. 2012;23:334-342.

136. Utiger RD. Effects of smoking on thyroid function. Eur J Endocrinol. 1998;138:368-369.

137. Seyler LE, Pomerleau OF, Fertig JB, et al. Pituitary hormone response to cigarette smoking. Pharmacol Biochem Behav. 1986;24:159-162.

138. Gossain VV, Sherma NK, Srivastava L, Michelakis AM, Rovner DR. Hormonal effects of smoking - 11: effects on plasma cortisol, growth hormone and prolactin. Am J Med Sci. 1986;291:325-327.

139. Wilkins JN, Carlson HE, Van Vunakis H, et al. Nicotine from cigarette smoking increases circulating levels of cortisol, growth hormone, and prolactin in male chronic smokers. Psychopharmacology. 1982;78:305-308.

140. Winternitz WW, Quillen D. Acute hormonal response to cigarette smoking. J Clin Pharmacol. 1977;17:389-397.

141. Kirschbaum C, Wust S, Strasburger CJ. Normal cigarette smoking increases free cortisol in habitual smokers. Life Sci. 1992;50:435-542.

142. Frederick SL, Reus VI, Ginsberg D, Hall SM, Munoz RF, Ellman G. Cortisol and response to dexamethasone as predictors of withdrawal distress and abstinence success in smokers. Biol Psychiatry. 1998;43:525-530.

143. Camlin NJ, McLaughlin EA, Holt JE. Through the smoke: use of in vivo and in vitro cigarette smoking models to elucidate its effect on female fertility. Toxicol Appl Pharmacol. 2014;281:266-275.

144. Windham GC, Elkin E, Swan SH, Waller KO, Fenster L. Cigarette smoking and effects on menstrual function. Obstet Gynaecol. 1999;93:59-65.

145. Kato I, Toniolo P, Koenig KL, et al. Epidemiologic correlates with menstrual cycle length in middle aged women. Eur J Epidemiol. 1999;15:809-814.

146. Chiolero A, Faeh D, Paccaud F, Cornuz J. Consequences of smoking for body weight, body fat distribution, and insulin resistance. Am J Clin Nutr. 2008;87:801-809.

147. Vandenberg LN, Colborn T, Hayes TB, et al. Hormones and endocrinedisrupting chemicals: low-dose effects and nonmonotonic dose responses. Endocr Rev. 2012;33:378-455.

148. Ino T. Maternal smoking during pregnancy and offspring obesity: meta-analysis. Pediatr Int. 2010;52:94-99.

149. Oken E, Levitan EB, Gillman MW. Maternal smoking during pregnancy and child overweight: systematic review and meta analysis. Int J Obes. 2008;32:201-210.

150. Koshy G, Delpisheh A, Brabin BJ. Dose response association of pregnancy cigarette smoke exposure, childhood stature, overweight and obesity. Eur J Public Health. 2011;21:286-291.

151. Bruin JE, Gerstein HC, Holloway AC. Long-term consequences of fetal and neonatal nicotine exposure: a critical review. Toxicol Sci. 2010;116:364-374.

152. Woods HF. Phytoestrogens and Health. Crown Copyright, The Food Standards Agency, London, UK: 2003.

153. Milligan SR, Kalita JC, Heyerick A, Rong H, De Cooman L, De Keukeleire D. Identification of a potent phytoestrogen in hops (Humulus lupulus L.) and beer. J Clin Endocrinol Metab. 1999;83:2249-2252.

154. Steinmann A. Health and societal effects from exposure to fragranced consumer products. Prevent Med Rep. 2017;5:45-47.

155. Henley DV, Lipson N, Korach KS, Bloch CA. Prepubertal gynecomastia linked to lavender and tea tree oils. NEngl J Med. 2007;356:479-485.

156. Kramer U, Herder C, Sugiri D, et al. Traffic-related air pollution and incident type 2 diabetes: results from the SALIA cohort study. Environ Health Perspect. 2010;118:1273-1279.

157. Weinmayr G, Hennig F, Fuks K, et al. Heinz Nixdorf Recall Investigator Group: Long-term exposure to fine particulate matter and incidence of type 2 diabetes mellitus in a cohort study: effects of total and trafficspecific air pollution. Environ Health. 2015;14:53.
158. Wolf K, Popp A, Schneider A, et al. Association between longterm exposure to air pollution and biomarkers related to insulin resistance, subclinical inflammation, and adipokines. Diabetes. 2016;65:3314-3326.

159. Harris RM, Mainwaring RH. Diethylstilboestrol - a long-term legacy. Maturitas. 2012;72:108-112.

160. Hu Y, Wen S, Yuan D, et al. The association between the environmental endocrine disruptor bisphenol A and polycystic ovary syndrome: a systematic review and meta-analysis. Gynecol Endocrinol. Epub 2017 Nov 30.

161. Carre J, Gatimel N, Moreau J, Parinaud J, Léandri R. Does air pollution play a role in infertility?: a systematic review. Environ Health 2017;16:82.

162. Bolden AL, Rochester JR, Schiltz K, Kwiatkowski CF. Polycyclic aromatic hydrocarbons and female reproductive health: a scoping review. Reprod Toxicol. 2017;73:61-74.

163. Fournier K, Tebby C, Zeman F, Glorennec P, Zmirou-Navier D, Bonvallot N. Multiple exposures to indoor contaminants: derivation of benchmark doses and relative potency factors based on male reprotoxic effects. Regul Toxicol Pharmacol. 2016;74:23-30.

164. Huang JV, Leung GM, Schooling CM. The association of air pollution with pubertal development: evidence from Hong Kong's "Children of 1997" birth cohort. Am J Epidemiol. 2017;185: 914-923.

165. McGinn LA, Voss RW, Laurent CA, Greenspan LC, Kushi LH, Windham GC. Residential proximity to traffic and female pubertal development. Environ Int. 2016;94:635-641.

166. Pedersen M, Giorgis-Allemand L, Bernard C, et al. Ambient air pollution and low birthweight: a European cohort study (ESCAPE). Lancet Respir Med. 2013;1:695-704.

167. Janssen BG, Saenen ND, Roels HA, et al. Fetal thyroid function, birth weight and in utero exposure to fine particle air pollution: a birth cohort study. Environ Health Perspect. 2017;125:699-705.

168. Hanahan D, Weinberg RA. Hallmarks of cancer: the next generation. Cell. 2011;144:646-674.

169. Hamra GB, Guha N, Cohen A, et al. Outdoor particulate matter exposure and lung cancer: A systematic review and meta-analysis. Environ Health Perspect. 2014;122:906-911.

170. Hamra GB, Laden F, Cohen AJ. Lung cancer and exposure to nitrogen dioxide and traffic: a systematic review and meta-analysis. Environ Health Perspect. 2015;123:1107-1112.

171. Lemjabbar-Alaoui H, Hassan OUI, Yang YW, Buchanan P. Lung cancer: biology and treatment options. Biochim Biophys Acta. 2015;1856:189-210.

172. Loomis D, Grosse Y, Lauby-Secretan B, et al. The carcinogenicity of outdoor air pollution. Lancet Oncol. 2013;14:1262-1263.

173. Santibáñez-Andrade M, Quezada-Maldonado EM, Osornio-Vargas Á, Sánchez-Pérez Y, García-Cuellar CM. Air pollution and genomic instability: the role of particulate matter in lung carcinogenesis. Environ Pollut. 2017;229:412-422.

174. Crouse DL, Goldberg MS, Ross NA, Chen H, Labrèche F. Postmenopausal breast cancer is associated with exposure to traffic-related air pollution in Montreal, Canada: a case-control study. Environ Health Perspect. 2010;118:1578-1583.

175. Hystad P, Villeneuve PJ, Goldberg MS, Crouse DL, Johnson K; Canadian Cancer Registries Epidemiology Research Group. Exposure to traffic-related air pollution and the risk of developing breast cancer among women in eight Canadian provinces: a case-control study. Environ Int. 2015;74:240-248.

176. Shmuel S, White AJ, Sandler DP. Residential exposure to vehicular traffic-related air pollution during childhood and breast cancer risk. Environ Res. 2017;159:257-263.

177. Large C, Wei Y. Geographic variations in female breast cancer incidence in relation to ambient air emissions of polycyclic aromatic hydrocarbons. Environ Sci Pollut Res. 2017;24:17874-17880. 
178. Scheurer ME, Danysh HE, Follen M, Lupo PJ. Association of trafficrelated hazardous air pollutants and cervical dysplasia in an urban multiethnic population: a cross-sectional study. Environ Health. 2014;13:52.

179. Lowcock EC, Cotterchio M, Ahmad N. Association between allergies, asthma, and breast cancer risk among women in Ontario, Canada. Cancer Causes Control. 2013;24:1053-1056.
180. Darbre PD, Fernandez MF. Environmental oestrogens and breast cancer: long-term low-dose effects of mixtures of varied chemical combinations. J Epidemiol Commun Health. 2013;67: 203-205.

181. Goodson WH, Lowe L, Carpenter DO, et al. Assessing the carcinogenic potential of low-dose exposures to chemical mixtures in the environment: the challenge ahead. Carcinogenesis. 2015;36:S254-S296.
International Journal of General Medicine

\section{Publish your work in this journal}

The International Journal of General Medicine is an international, peer-reviewed open-access journal that focuses on general and internal medicine, pathogenesis, epidemiology, diagnosis, monitoring and treatment protocols. The journal is characterized by the rapid reporting of reviews, original research and clinical studies across all disease areas.

\section{Dovepress}

The manuscript management system is completely online and includes a very quick and fair peer-review system, which is all easy to use. Visit http://www.dovepress.com/testimonials.php to read real quotes from published authors.

Submit your manuscript here: https://www.dovepress.com/international-journal-of-general-medicine-journal 